\title{
Ilustracja książek dla dzieci jako źródło dylematów tłumacza - na przykładzie dwóch niemieckich przekładów Le Petit Prince Antoine'a de Saint-Exupéry'ego
}

\section{Illustrations in picturebooks as a source of translator's dilemmas - two German translations of Le Petit Prince by Antoine de Saint-Exupéry}

\author{
Beate Sommerfeld \\ INSTYTUT FILOLOGII GERMAŃSKIEJ, UNIWERSYTET ADAMA MICKIEWICZA \\ 61874 POZNAŃ \\ bsommereamu .edu.pl
}

\begin{abstract}
The article deals with translator's dilemmas in the context of picturebooks on the example of the new translations of the French classic "Le Petit Prince" by Antoine de Saint-Exupéry. Given the intermedia character or illustrated books for children, their translation is a very demanding task. It requires 'visual literacy', the ability of 'reading' and understanding pictures. The way, in which the translators cope with the interplay between the verbal and the visual, so essential for picturebooks, allows to discern their translation strategies. The examined examples point out the discrepancies between domesticating translation and the original illustrations and also the impact of new illustration on the target text. The example of Hans Magnus Enzensberger shows to what extent the original illustrations can be a disruptive factor in adapting translation, so that the only solution is to ignore the intermedia character of the source text. Such manipulation results in the empoverishment of the text. In the case of Peter Sloterdijk his demand for new illustrations can be considered as a consequence of the re-contextualization, that can be observed in his translation.
\end{abstract}




\section{Wstęp}

Jedna z najsłynniejszych opowieści literatury dziecięcej, Alicja $w$ Krainie Czarów, rozpoczyna się od rozważań nad ważną rolą ilustracji: „Po co komu taka książka - pomyślała Alicja - w której nie ma ani obrazków, ani dialogów” (Caroll 2010: 13) - zastanawia się bohaterka biorąc do ręki książkę. Obrazki są niezwykle istotne dla odbioru ilustrowanych książek dla dzieci (por. Nodelman / Meek 1990, Lewis 2001). Najpowszechniejszym sposobem tworzenia ilustracji jest ich kreowanie ex post - powstają wówczas „obrazowe wizje” dodawane przez artystę do gotowego już dzieła literackiego (por. Wysłouch 1994: 100), inspirowane słowem. Ilustracja, zwłaszcza autorska, może też powstać równolegle z tekstem jak obrazki zamieszczone $\mathrm{w}$ książce Le Petit Prince Antoine'a de SaintExupéry'ego.

Tekst i ilustracja pełnią równorzędne funkcje estetyczne. Przekaz wizualny nie powinien być lekceważony, ani traktowany jako czysty ozdobnik albo dodatek do tekstu werbalnego, zwłaszcza gdy książka jest czytana przez dorosłego, siedzącego obok, słuchacz jest jednocześnie widzem wpatrującym się w obrazy. Jak pisze Peter Hunt (2005: 8), ilustrowana książka jest odbierana przez dziecko jako całość, na którą się składają tekst werbalny i rysunki: „[...] the experience of a book starts before - and goes beyond - the words or the pictures on the page. The total book as-object is an experience, one that has become elementary". Książka dziecięca stanowiąc całość nie może rozpadać się na słowa i obraz, musi stworzyć wspólny, polisensoryczny przekaz. Ilustracje nie stanowią więc obojętnego sąsiedztwa tekstu, lecz wchodzą z nim w dialog albo wzbogacają go o nowe znaczenia.

Dialog między tekstem a obrazem opisują funkcjonalne klasyfikacje wzajemnych relacji kodu lingwalno-symbolicznego i znaków ikonicznych oraz zachodzących w nich procesów znaczeniotwórczych. Najbardziej znanym jest model Kressa i van Leeuwena (2006). W oparciu o koncepcję Halliday'a (1978) badacze ci rozróżniają między funkcją reprezentacyjną i interaktywną określającą zdolność do komunikacji emocji i postaw (por. Kress, van Leeuwen 2006: 114f) oraz tekstową (ibidem: 41), odnoszącą się do wspóltworzenia spójnej kompozycji dzieła (ibidem: 175ff). Model uwzględnia nie tylko interakcję kodu lingwalnosymbolicznego i ikonicznego, ale obejmuje także aspekt pragmatyczny, który nabiera szczególnego znaczenia w świetle performatywnego charakteru literatury dla dzieci, realizującego się podczas czytania na głos. Zmiany w kolejności tekstu i obrazu oraz ich wielkości, rozmieszczenie ilustracji na kolejnych stronach pociągają za sobą modyfikacje $\mathrm{w}$ warstwie performatywnej. Na kolejną funkcję elementów obrazu wskazuje klasyfikacja Nefzera (1993), w której obok ilustracji ukierunkowanych na odzwierciedlenie przebiegu akcji i przekazywanie treści (ibidem: 25f) oraz form ilustrowania, które "grają" na emocjach i pobudzają wyobraźnię (ibidem: 28), rozróżnia się ilustracje eksplorujące idee wyrażane w tekście werbalnym oraz interpretujące go środkami wizualnymi (ibidem: 32f). Podobnie Katarzyna Wądolny-Tatar (2016: 101) rozróżnia ilustracje o charakterze 
Beate Sommerfeld: Ilustracja książek dla dzieci jako źródło dylematów tłumacza na przykładzie dwóch niemieckich przekładów Le Petit Prince

Antoine'a de Saint-Exupéry'ego

realistyczno-mimetycznym oraz metaforycznym, $\mathrm{z}$ wyraźną funkcją interpretacyjną. Także klasyfikacja Bogumiły Kaniewskiej (2016: 172) polaryzuje zabiegi konkretyzacji, gdy ilustracje wpisują się w konwencję tekstu, wzmacniają przekaz estetyczny, uwypuklając jego cechy, oraz ilustracje o charakterze interpretacyjnym, które wchodzą $\mathrm{w}$ jawny dialog $\mathrm{z}$ tekstem, poprzez anachronizm, modernizację albo zastosowanie obcej tekstowi konwencji estetycznej. W drugim przypadku dochodzi do poszerzenia znaczeń, swoistego otwarcia tekstu. ${ }^{1}$

Uwzględnianie intermedialnego charakteru ilustrowanych książek dla dzieci jest szczególnym wyzwaniem dla tłumacza. Do pierwszych badaczy, którzy zwrócili uwagę na problem ilustracji w przekładzie literatury dziecięcej, należą Birgit Stolt (1978: 130-140) oraz Izabel da Silva (1991: 7f). Dzisiaj w odniesieniu do przekładu literatury dla dzieci istnieje zgoda co do konieczności uwzględnienia w tłumaczeniu elementów obrazowych i innych detali wizualnych (por. Sommerfeld 2016: 92-96, 2017a: 48-51). Oittinen (2000: 101) traktuje ilustracje jako integralną część tekstu i mówi o dialogu między słowem a obrazem, który należy uwzględnić $\mathrm{w}$ przekładzie. Badaczka podkreśla konstruktywny charakter interakcji tekstu z obrazem, rozgrywającej się w świadomości tłumacza (ibidem: 100). Ilustracje wpływają znacząco na wyobrażenia przywoływane przez tekst werbalny (por. da Silva 1991: 3), najczęściej konkretyzując niedookreślenia w tekście (por. Tabbert 2002: 318). Brigitte Schultze (2007: 166of) mówi o interaktywnej bi-medialności oddziałującej $\mathrm{w}$ znaczącej mierze na proces znaczeniotwórczy, w który jest uwikłany tłumacz. Ilustracje mają też swój udział w konstruowaniu implicytnego odbiorcy, mogą wspierać podwójnego adresata (ibidim: 1660), a tym samym wzbogacać potencjał znaczeniowy i estetyczny tekstu. Adekwatne podejście do ilustrowanych książek dla dzieci ze strony krytyki przekładu wymaga zatem szerokiej perspektywy badawczej, która obejmuje zarówno kod werbalny jak i wizualny. Tłumacz powinien posiadać umiejętność „czytania” obrazów. Taką kompetencję niezbędną do tłumaczenia ilustrowanych książek dla dzieci Kate Raney (1998: 8) określa jako „visual literacy”: obejmuje ona "the history of thinking about what images and objects mean, how they are put together, how we respond to or interpret them, how they might function as modes of thought". Riitta Oittinen (2000: 101) z kolej mówi o "the ability to read pictures, too, in the same way as they need the ability to read and write foreign written and spoken languages."

Jednym $\mathrm{z}$ najczęstszych rozwiązań $\mathrm{w}$ przypadku przekładów ilustrowanych książek dla dzieci jest wykorzystanie klasycznych, oryginalnych ilustracji. W przypadku obranej przez tłumacza strategii adaptacyjnej może dochodzić do rozdźwięku między tekstem werbalnym a towarzyszącymi mu obrazkami. Adaptacje są częstym zjawiskiem w przekładzie dla dzieci, co opisano już w tomie wydanym przez Göte Klingberga Children's Books in Translation (1978) (por. także Reiß 1982: 7f). Zohar Shavit (1986: 64f) rozpatruje kwestię adaptacji w

\footnotetext{
${ }^{1} \mathrm{Na}$ funkcję interpretacyjną ilustracji do książek dla dzieci zwraca uwagę także Oittinen (2000: 103).
} 
przekładzie literatury dla dzieci przez pryzmat jej peryferyjnej pozycji $\mathrm{w}$ polisystemie literatury, która legitymizuje wszelkie ingerencje $\mathrm{w}$ tekst celem dostosowywania go do norm obowiązujących w kulturze docelowej. Tym samym literatura dziecięca staje się szczególnie podatna na różnorakie manipulacje. Tendencję do manipulowania tekstem przedstawia Juliane House (2004: 683697), wykazując, że „dla dobra dziecka” albo w imieniu poprawności politycznej tłumacze przemycają wiele ukrytych wartości, kierując się normami kultury docelowej. Chęć manipulowania tekstem, dodawanie do niego niekiedy pedagogicznie motywowanych zamierzeń, przejawia się w przyznawaniu sobie kompetencji autorskiej przez tłumaczy. Emer O'Sullivan (2000: 241-257) wprowadza pojęcie „implicytnego tłumacza”, którego głos nie musi się pokrywać z głosem autora/narratora, a może go wręcz czynić niesłyszalnym. Również Gilian Lathey (2010: 83f) pisze o ukrytych w przekładzie narratorach, którzy zagłuszają idiom autora tak skutecznie, że czytelnik nie rozpoznaje, że ma do czynienia z tekstem tłumaczonym. Wybór strategii covert translation (Juliane House 1997: 161ff) prowadzi do zubożenia znaczeniowego i estetycznego potencjału tekstów wyjściowych. Szczególną rolę odgrywa to $\mathrm{w}$ przypadku tekstów skierowanych zarówno do dziecka jak i do czytelnika dorosłego (por. O’Sullivan 1994: 131-153). Takie teksty z modelowym podwójnym adresatem są - jak wskazuje Shavit (1986: 63-91) - tekstami ambiwalentnymi, niosącymi wiele implicytnych, ukrytych znaczeń.

Dylematy tłumacza $\mathrm{w}$ zderzeniu $\mathrm{z}$ oryginalnymi ilustracjami do książek $\mathrm{w}$ niniejszym artykule są badane na przykładzie dwóch nowych niemieckich przekładów francuskiego klasyka Le Petit Prince Antoine’a de Saint-Exupéry'ego, ukazując strategie tłumacza $\mathrm{w}$ odniesieniu do interakcji między słowem a obrazem, na której opiera się oryginał.

\section{Le Petit Prince Antoine'a de Saint-Exupéry'ego i jego niemieckie przekłady}

Le Petit Prince należy do książek adresowanych zarówno do dzieci jak i dorosłych. Jest to tekst wysoce ambiwalentny (Shavit 1986: 63-91), który cechuje się gatunkową hybrydycznością. Można go określić jako baśń filozoficzną. W tekście dialogi nacechowane dziecięcym rejestrem językowym przeplatają się $\mathrm{z}$ sentencjami filozoficznymi, które wpisują się w kontekst szeroko pojętego egzystencjalizmu. Sygnałem obecności wpisanego w tekst podwójnego adresata jest dedykacja, autor dedykuje swój tekst przyjacielowi Léonowi Werthowi, kiedy ten był jeszcze dzieckiem. Innym sygnałem są również ilustracje wykonane przez autora. Rysunki akcentują obecność dziecka w tekście pokazując emocje odmalowujące się na twarzy i w gestach dziecięcego bohatera oraz dramatyzm jego zmagań z przeciwnościami losu. W Le Petit Prince oryginalne rysunki nie zawierają żadnych elementów, które nie służyłyby orientacji, nakreśleniu scenerii. Są one wyraźnie osadzone w fabule i nie wychodzą poza elementy w niej zawarte. Za Kaniewską (2016: 172) można je określić jako zabiegi konkretyzacji, gdyż wpisują się $\mathrm{w}$ konwencję tekstu, korespondują $\mathrm{z}$ przekazem estetycznym. 
Beate Sommerfeld: Ilustracja książek dla dzieci jako źródło dylematów tłumacza na przykładzie dwóch niemieckich przekładów Le Petit Prince Antoine'a de Saint-Exupéry'ego

Podstawą estetyki rysunków francuskiego autora jest ich, nieporadna kreska, sprawiająca wrażenie narysowanej dziecięcą dłonią - plastyczny ekwiwalent sytuacji narracyjnej, w której przeważa perspektywa dziecka. Dorosły narrator pozostaje dyskretnie $\mathrm{w}$ tle, a próbę porozumienia się $\mathrm{z}$ dzieckiem podejmuje właśnie poprzez rysunki.

Ilustracje francuskiego autora uwypuklają przebieg akcji i grają na emocjach i wyobraźni odbiorcy. Wyraźna jest $\mathrm{w}$ nich funkcja interaktywna określająca zdolność do komunikowania emocji i postaw (por. Kress / van Leeuwen 2006: 114f). Zaakcentowana jest warstwa performatywna: tekst wielokrotnie nawiązuje do ilustracji, co zwiększa jego dramaturgię i sugestywność odbioru przez dziecięcego czytelnika. Ilustracje mają poza tym funkcję tekstową (ibidem: 175ff): nadają bowiem tekstowi spójność i wspóltworzą jego rytm; za sprawą ilustracji tekst nabiera niekiedy tempa i dramatyzmu, niekiedy zaś spowalniają przebieg akcji i nakłaniają do refleksji. Tam gdzie ilustracje zajmują całą stronę i zostały opatrzone podtytułami, które tworzą dodatkowe relacje intermedialne i powtarzają centralne filozoficzne przesłanie, podążają one za sensem tekstu (por. Nefzer 1993: 26). Współtworząc równowagę między światem dziecięcym a filozoficzną refleksją, ilustracje podkreślają, że tekst francuskiego filozofa jest skierowany do podwójnego odbiorcy. Relacje tekstu z obrazem stanowią więc przemyślany układ - ani kolejność, ani ich wielkość względem tekstu nie są przypadkowe.

Jak sobie poradzili tłumacze $\mathrm{z}$ wyzwaniem rzuconym przez oryginał? Pierwsze tłumaczenie wykonane przez Josepha i Grete Leitgeb (1950) ukazało się w wydawnictwie Karl Rauch, będącym posiadaczem praw autorskich. W roku 2009 pojawił się nowy przekład renomowanej tłumaczki Elisabeth Edl. W roku 2014, 70 lat po zaginięciu autora, wygasły prawa autorskie, co zainicjowało falę nowych przekładów francuskiego klasyka. Wykonali je m.in. Ulrich Bossier (2015), Peter Stamm (2015), autor cenionych powieści, Hans Magnus Enzensberger (2015), jeden z najbardziej znanych autorów niemieckojęzycznych „pokolenia 68” oraz Peter Sloterdijk (2015), wybitny filozof z kręgu postmodernizmu. Jego przekład jako jedyny został - na życzenie jego autora - opatrzony nowymi ilustracjami, które wykonał Nicolas Mahler, znany austriacki autor komiksowych adaptacji dzieł literatury światowej.

W przeważającej większości tłumacze kierują się zasadą tłumaczenia wiernego, podążają za tekstem oryginału redukując adaptację do minimum. Adaptacje kontekstowe nie występują wcale, przekłady są osadzone w kulturze wyjściowej. Mamy więc do czynienia z przypadkami overt translation (House 1997: 161f), które nie ukrywa swojego statusu tekstu tłumaczonego. Wprowadzono jedynie lekkie adaptacje językowe, modyfikujące nieco pierwotne tłumaczenie Leitgebów, uwspółcześniając je poprzez wyeliminowanie stylistycznych nieporadności wynikających ze zbyt dosłownego tłumaczenia. Zarówno przekład Edl, jak i Stamma oraz Bossier'a tylko minimalnie ingerują $\mathrm{w}$ warstwę językowostylistyczną tekstu. Tłumacze dbają o zachowanie estetycznych walorów oryginału. Wszystkie cechy tekstu, które czynią go atrakcyjnym dla dziecięcego 
ucha $\mathrm{w}$ odbiorze audytywnym podczas czytania na głos, rymy, wszelkie redundancje dźwiękowe, radosna playfulness oryginału zostały troskliwie odwzorowane. Tłumacze nie ingerują $\mathrm{w}$ warstwę performatywną oryginału. Układ tekstu i obrazów - łącznie z podtytułami do ilustracji - został starannie odwzorowany, a tekst przetłumaczono tak, aby zachować wszystkie nawiązania do ilustracji. Uwzględnienie intermedialnego charakteru pierwowzoru idzie w parze $\mathrm{z}$ zabiegami translatorskimi dbającymi o równowagę między dziecięcym rejestrem językowym a sygnaturą filozoficzną oryginału i przyczynia się do zachowania hybrydycznego charakteru tekstu. Dwa przekłady wyłamują się z tej ogólnej tendencji i dlatego proponuję, aby przyjrzeć się im dokładniej. Są to przekłady Hansa-Magnusa Enzensbergera oraz duetu Sloterdijk i Mahler. ${ }^{2}$

\section{Hans Magnus Enzensberger}

Niemiecki pisarz obrał w stosunku do oryginału strategię adaptującą. Adaptacje dotyczą przede wszystkim sfery werbalnej: dialogi nie tylko zachowują styl języka mówionego, lecz również zostały dopasowane do rejestru językowego współczesnego dziecka. Przekład Enzensbergera obfituje w kolokwializmy: bohater przyznaje, że „zwiał” (abgehauen) ze swojej planety i skarży się, że dorośli niczego nie „kapują” (kapieren) (St. Exupéry 2015b: 31). W przeciwieństwie do wcześniejszych niemieckich przekładów, strategię zastosowaną przez Enzensbergera określić można mianem covert translation (House 1997: 161ff), w której tłumaczeniu przypisywany jest status oryginału. Niemiecki czytelnik będzie miał wrażenie, że czyta całkiem niezależny tekst, cechujący się taką samą niesubordynacją wobec oryginału jak jego filuterny bohater wobec dorosłego - pilota, z którym spotkał się na afrykańskiej pustyni. Enzensberger bowiem najwyraźniej wnosi do tekstu swoje wyobrażenia o dziecku, dzieciństwie, ale też o relacjach osoby dorosłej z dzieckiem (por. Oittinen 2000: 4). Dziecięcy bohater modelowany w tekście Enzensbergera jest znacznie bardziej zadziorny i krytycznie nastawiony do wszelkich autorytetów niż jego pierwowzór. Podczas gdy w oryginale pogrążony w myślach bohater nie słyszy zadawanych mu pytań (ne semblait jamais entendre les questions) (St. Exupéry 1943: 15), u Enzensbergera nie „słucha” on swoich dorosłych interlokutorów (hat er einfach nicht hingehört) (St. Exupéry 2015b: 15). U Saint-Exupéry'ego Mały Książę jest istotą głęboko metafizyczną, która wprowadza pilota-narratora i czytelnika w tajemnice ludzkiego istnienia, niemiecki tłumacz natomiast opisuje swojego bohatera jako małego zawadiakę, realistycznie patrzącego na otaczający go świat. 3 Takie decyzje tłumacza prowadzą do znacznego spłaszczenia obrazu głównej postaci, której w wydaniu Enzensbergera brakuje wszystkiego, co

\footnotetext{
${ }^{2}$ Dla szczegółowej analizy niemieckich przekładów Małego Księcia por. Sommerfeld (2017: 69-83, 2017a: 70-82).

${ }^{3}$ Enzensberger postępuje $\mathrm{w}$ zgodzie $\mathrm{z}$ normami obowiązującymi w niemieckiej literaturze dziecięcej pokolenia ' 68 , które wymaga od tekstów wychowywania w duchu krytycznym i nosi znamiona swoistej ,anty-pedagogiki” (por. House 2004: 693f).
} 
Beate Sommerfeld: Ilustracja książek dla dzieci jako źródło dylematów tłumacza na przykładzie dwóch niemieckich przekładów Le Petit Prince Antoine'a de Saint-Exupéry'ego

niewytłumaczalne, przede wszystkim melancholii wynikającej ze świadomości kondycji ludzkiej. Stwierdzenie bohatera, że jest mu „strasznie smutno” (Je suis tellement triste...) (St. Exupéry 1943: 67), w przekładzie zostało pominięte (St. Exupéry 2015b: 91). Tekst Enzensbergera jest skierowany wyłącznie do współczesnego dziecka, nie uwzględnia natomiast ukrytego w dziecku dorosłego czytelnika, tak jak tego chce autor. Zarzucić mu więc można nie tylko brak stylistycznej koherencji z oryginałem, ale i wygładzanie hybrydyczności tekstu wyjściowego. Sygnałem eliminacji podwójnego adresata wpisanego w oryginał jest przemieszczenie dedykacji z początku, gdzie „nadaje ona ton” tekstowi, na jego koniec.

Mamy więc do czynienia ze znaczącą modyfikacją modelowego czytelnika, ale też słyszalny staje się głos implicytnego tłumacza (por. O’Sullivan 2000: 241-257). Jest to adaptacja naznaczona pedagogicznymi ambicjami tłumacza, który występuje w roli nauczyciela wyjaśniającego niejasności. Kluczowe dla oryginału, wieloznaczne pojęcie „oswojenia” (apprivoiser) (St. Exupéry 1943: 67) zostało zastąpione wyjaśnieniem, czym jest „zwierzę domowe” (Haustier) (St. Exupéry 2015b: 91), a „widzenie oczyma”, które we francuskim tekście otwiera szerokie pole semantyczne, w przekładzie staje się aktem „zrozumienia” (begreifen) (ibidem: 96). Takie manipulacje tekstem legitymizuje dążność tłumacza do dopasowania tekstu do (domniemanych przez tłumacza) możliwości kognitywnych dziecka. Tłumacz - dla „dobra dziecka” - zrezygnował z wielopłaszczyznowego odczytania oryginału, podczas gdy francuski tekst jest pełen niedopowiedzeń i cechuje go estetyka sugestii oraz implicytnych znaczeń, przekład kładzie nacisk na przekazywanie konkretnych treści i dąży do klarowności. Skłonność do nadmiernego eksplikowania, która nie pozostawia czytelnikom marginesu do skonstruowania własnych interpretacji, można zdaniem House (2004: 692) zaobserwować u niemieckich tłumaczy pokolenia '68, do którego należy Enzensberger.

Manipulowany przez tłumacza tekst koresponduje $\mathrm{z}$ oryginalnymi rysunkami autora tylko $\mathrm{w}$ jednym wymiarze: kiedy jest on adresowany do współczesnego dziecka i odwołuje się do świata dziecięcych doświadczeń. Tam, gdzie tekst skupia się na oddaniu fabuły, pasują do niego ilustracje francuskiego autora, które podążają za przebiegiem akcji i uwypuklają jej dramatyzm. Dziecięcy rejestr językowy współgra z rysunkami przedstawiającymi emocje bohatera (Nefzer 1993: 28, Kress, van Leeuwen 2006: 114f). Natomiast w miejscach, gdzie ilustracje stanowią zachętę do refleksji, swawolny tekst Enzensbergera nie przystaje już do nich. Tu tłumacz wykazuje brak kompetencji „visual literacy” (por. Raney 1998: 8, Oittinen 2000: 101): Ewokowane przez tekst wyobrażenia bohatera kolidują z ilustracjami ukazującymi delikatne dziecko o melancholijnym usposobieniu, a wywołane przez tekst przekładu scenes nie pokrywają się z tymi przedstawionymi w ilustracjach i muszą wywoływać irytację u odbiorcy. Także na poziomie stylu powstaje niezgodność: delikatne pastele i ckliwość rysunków nie korespondują z dosadnością przekazu tekstowego. W momentach, gdy bohater przygląda się zachodom słońca, płacze nad utraconą miłością i prowadzi rozmowę o śmierci, odsłania się głęboka warstwa znaczeniowa przypowieści Saint 
Exupéry'ego. To właśnie tutaj - w postaci podtytułów do ilustracji - zawiązuje się najsilniejsza interakcja między słowem a obrazem. Dysonans między tekstem Enzensbergera a rysunkami autora uwidacznia się w ich pomijaniu, przez co znikają w przekładzie ważne relacje intermedialne. Wskutek takich zabiegów zatraceniu ulega $\mathrm{w}$ znacznej mierze dynamika oryginału, jego performatywny charakter. Narracja w przekładzie Enzensbergera rozwija się obok ilustracji, takie lekceważenie warstwy wizualnej oryginału prowadzi w efekcie do wygładzenia hybrydyczności oryginału. Bez oparcia w oryginalnych rysunkach francuskiego autora przekład Enzensbergera jest odarty $\mathrm{z}$ odniesień intermedialnych, precyzyjnie wpisanych $\mathrm{w}$ oryginal. Daje niemieckim czytelnikom tylko jedną warstwę znaczeniową dzieła oryginalnego, wygładzając wieloznaczność tekstu.

\section{Peter Sloterdijk / Nicolas Mahler}

Niemiecki filozof Peter Sloterdijk wybiera przeciwną do Enzensbergera strategię przekładu - jego tekst jest skierowany do dorosłego czytelnika, dlatego jest wolny od wszelkich zabiegów adaptujących go do świata dziecięcych wyobrażeń. Podczas gdy Enzensberger eliminuje abstrakcyjne pojęcia, Sloterdijk ekstrapoluje filozoficzne przesłanie: wszystkie sentencje zostały przetłumaczone wiernie nawet wtedy, gdy stawiają wysokie wymagania odbiorcy. W wersji Sloterdijka Mały Książę staje się 'porte-parole' tłumacza, zajmuje zdystansowaną pozycję wobec świata i patrzy na niego z pobłażliwą ironią. Świat dorosłych jest dla niego „śmieszny ... a w dodatku dość poetycki. Ale nie można go traktować poważnie” (amüsant ... obendrein ziemlich poetisch. Aber ernst ist das nicht) (SL 53). Także wobec kondycji ludzkiego życia przybiera lakoniczny ton, kiedy np. bohater w obliczu śmierci mówi: „Voilà ... i to by było na tyle.” (Voilà ... das war es) (SL 94). Nie tylko w hybrydyzacji bohatera, ale również w stylistycznej heterogeniczności przekładu Sloterdijka ujawnia się dystans do przedstawionego świata. W przeważającej części tekst zachowuje lakoniczny charakter, ale w niektórych miejscach przybiera liryczny ton, przez co nie tylko zachowuje ambiwalencję oryginału, który (wzorem baśni filozoficznej) oscyluje między tonem realistycznym i baśniowym, ale eksponuje też swój własny szkicowy charakter. Burząc koherencję tekstu, tłumacz kwestionuje status przekładu jako skończonego dzieła. Tekst zachowuje ślady transferu językowego, i zdradza swój status tłumaczonego tekstu: w wypowiedziach głównego bohatera występują liczne kalki z języka francuskiego: „Voilà” (SL 94), „ephemer” (SL 60), „bizarr” (SL 18), „monoton” (SL 73), „Desaster” (SL 26). Mają one się nijak do języka dziecka, i wskazują na auto-referencyjność przekładu, który inscenizuje swoje intertekstualne powiązanie z oryginałem.

Tłumacz rozwija je w obszernym posłowiu, w którym przekład przekracza własne granice i uczestniczy w dialogu tekstów i dyskursów. „Implicytny tłumacz” (por. O'Sullivan 2000: 241-257), który dochodzi do głosu w przekładzie Sloterdijka, przypisuje sobie rolę „dyspozytora” tekstów i dyskursów, układającego je w nowe porządki i otwierającego tekst na nowe odczytania. Takie relatywizujące i auto- 
Beate Sommerfeld: Ilustracja książek dla dzieci jako źródło dylematów tłumacza na przykładzie dwóch niemieckich przekładów Le Petit Prince Antoine'a de Saint-Exupéry'ego

referencyjne zabiegi translatorskie $\mathrm{z}$ silnie akcentowaną intertekstualnością wpisują się $\mathrm{w}$ postmodernistyczną praktykę translatorską, która ironiczny stosunek postmodernizmu nie tylko do oryginału, ale także do idei oryginału, realizuje jako formę komentowania i cytowania (por. Balcerzan 1998: 174ff).

Ten rys auto-referencyjnej ironii, który zostawia ślad w przekładzie Sloterdijka, został podkreślony przez ilustracje Nicolasa Mahlera, austriackiego rysownika znanego przede wszystkim z komiksowych adaptacji dzieł literatury światowej. W ilustracje Mahlera są wpisane intertekstualność i ironia, w przekraczaniu granicy między pop-kulturą a kulturą wysoką ujawnia się postmodernistyczny impuls jego adaptacji komiksowych. Rysunki wpisują się w ironiczny dialog z tekstem wyjściowym, który cechuje przekład Sloterdijka. Dezynwoltura w stosunku do pierwowzorów wskazują na kpiący stosunek do dzieła oryginalnego: wszystkie adaptacje komiksowe Mahlera mają karykaturalny charakter, ich cechą rozpoznawczą jest nieproporcjonalnie duży nos głównej postaci, który wywołuje efekt komizmu. Komizm wynika też $\mathrm{z}$ kontrastu rysunków $\mathrm{z}$ tekstem, przedstawiają one bowiem głównego bohatera jako postać dorosłą. Ale rysunki Mahlera nie mają wyłącznie prześmiewczego charakteru; niekiedy są naznaczone melancholią, balansują między ironią a powagą, wydobywają ambiwalencję ukrytą $\mathrm{w}$ oryginale, dzięki czemu tworzą wizualny odpowiednik przekładu Sloterdijka. Dynamiczna relacja zachodząca między tekstem a obrazem, która się jawi w propozycji Sloterdijka i Mahlera, jest przykładem tego, co zdaniem Salisbury i Styles (2012: 89) cechuje postmodernistyczne ilustrowanie książki dla dzieci: "a playful dance, where images and words can appear to flirt with and contradict each other".

Ilustracje Mahlera wchodzą $\mathrm{w}$ jawny dialog $\mathrm{z}$ tekstem, poprzez zastosowanie obcej tekstowi konwencji estetycznej (por. Kaniewska 2016: 172). Pozostając w relacji niespójności z tekstem, ilustracje wzmagają heterogeniczność przekładu i jednocześnie kwestionują wyobrażenie o organicznym związku słowa i obrazu. Kiedy ilustracje dekonstruują tekst, powstaje rozdźwięk między przekazem werbalnym i wizualnym. Mahler postępuje w zgodzie z nowszymi osiągnięciami komiksu, w których relacje między tekstem a obrazem zawiązują się i rozpadają (por. Kaźmierska-Jerzyk 2010: 51f) - eksperymentalną estetyką komiksu wchodzi $\mathrm{w}$ interakcję $\mathrm{z}$ tekstem przekładu i wzbogaca go o nowe konteksty. Zarazem Mahler wpisuje się w nowsze praktyki ilustrowania książek dla dzieci, w których obrazki są wyrafinowanymi igraszkami odznaczającymi się wieloznacznością i ironią (por. O’Sullivan 2000: 277). Jak piszą Salisbury i Styles (2012: 75) o postmodernistycznych książkach dla dzieci, żyjemy w „a so-called postmodern age where playfulness, rule-breaking, fragmentation and uncertainty are commonplace (and feature in many challenging picturebooks)", zawierają one "demanding themes, sophisticated artistic styles, complexe ideas and the implied notion of a reader as someone who will relish these challenges" (ibidem).

Przesunięcie gatunkowe od ilustrowanej książki dla dzieci w kierunku estetyki komiksowej powoduje fundamentalną zmianę relacji obraz / tekst polegającą na podniesieniu rangi obrazu w relacji do tekstu. Ale też sposób, w jaki obraz jest "odczytywany”, jest przedmiotem gatunkowej interferencji. Rysunki Mahlera 
ukazują swój semiotyczny wymiar poprzez redukcję, która zbliża je do znaków językowych. Wysyłają w ten sposób nie tylko sygnał do odczytania (por. SchmitzEmans 2015: 21), ale i podważają granicę między obrazem a słowem. Wszystkie elementy $\mathrm{w}$ komiksie są poddawane zabiegom semiotyzacji i mogą przyjąc funkcję cytatów wizualnych. W ten sposób komiksowe ilustracje Mahlera prowadzą subtelną grę inter-ikoniczną nie tylko z rysunkami oryginału - wtedy gdy odtwarzają poszczególne elementy, takie jak jasnoblond czupryna albo żółty szalik głównego bohatera - ale też z wcześniejszymi ilustracjami rysownika, który zdążył już wypracować rozpoznawalny styl. Cytaty wizualne odsyłające do własnej twórczości nadają ilustracjom element auto-referencyjny, dzięki czemu powstaje swoista hipertekstualność. Tym samym jego ilustracje wpisują się w cytatowy, autoironiczny charakter tekstu przekładu w takim samym stopniu jak tekst, który nie ukrywa swojej wtórności względem oryginału. Podobnie jak tekst przekładu, realizują one poetykę zapożyczenia i recyklingu, są zbiorem zremiksowanych cytatów o różnej proweniencji. Dzięki silnie zaakcentowanej inter-ikoniczności na równi z tekstem prezentują się jako jeden z możliwych komentarzy do tekstu wyjściowego. 4

$\mathrm{Na}$ hybrydyczność tekstu wyjściowego ilustracje Mahlera reagują środkami specyficznymi dla własnego medium: swoją abstrakcyjnością wpasowują się $\mathrm{w}$ filozoficzny ton przekładu Sloterdijka, zachowują jednak stylistykę naiwnych, nieco niewprawnych rysunków dziecięcych. Każdy z tych zabiegów wnosi nowe elementy semantyczne do samego tekstu i buduje jego kolejną wersję. Głównie za sprawą ilustracji przekład Sloterdijka i Mahlera staje się tekstem wysoce ambiwalentnym. Rysunki dążą do zachowania wieloznaczności oryginału i realizują estetykę implicytnych znaczeń, ich abstrakcyjny charakter koresponduje z aluzyjnością francuskiego oryginału, a poprzez redukcję unikają konkretyzacji niedookreśleń, które pozostawia tekst. Rysunki Mahlera odchodzą od paradygmatu reprezentacji i skupiają się na ideach obecnych $\mathrm{w}$ tekście werbalnym (por. Nefzer 1993: 28), przedstawiając je za pomocą symboli: butelki reprezentują pijaka, korona symbolizuje żądzę władzy, a lustro próżność i krążenie wokół własnego ja. Mahler w ten sposób tworzy metafory, które „można zobaczyć" (Porębski 1980). Jego ilustracje nie są zatem obliczone na pobudzanie wyobraźni, zamiast tego wyzwalają procesy konceptualizacji, przy czym Mahler umiejętnie wykorzystuje estetykę komiksową, w której granica między obrazem a symbolem jest płynna (por. Mc Cloud 2006: 31). Takie strategie ilustrowania korespondują z tekstem przekładu Sloterdijka, eksponującym filozoficzne idee zawarte w oryginale.

Temu celowi służą też zmiany w kolejności tekstu i ilustracji, których dokonuje Mahler: rysunki kilkakrotnie zostają przesunięte na koniec epizodów, co nadaje im charakter puenty. W kilku miejscach Mahler dodaje ilustracje: w rozdziale XXI. pojawia się dodatkowy rysunek przedstawiający lisa wyjaśniającego akt „oswojenia”, który zawiera symboliczny element smyczy. Po ostatnim epizodzie

\footnotetext{
${ }^{4} \mathrm{Na}$ odniesienia interpikturalne i powiązania intertekstualne $\mathrm{w}$ postmodernistycznych ilustrowanych książkach dla dzieci wskazuje O’Sullivan (2000: 278).
} 
Beate Sommerfeld: Ilustracja książek dla dzieci jako źródło dylematów tłumacza na przykładzie dwóch niemieckich przekładów Le Petit Prince Antoine'a de Saint-Exupéry'ego

ponownie widzimy rysunek pudełka, który pojawia się w rozdziale II., gdzie pilot narysował pudełko zawierające niewidzialną owcę. Rysunek ten jest wierną kopią oryginalnej ilustracji, przez co staje się cytatem wizualnym, a zarazem wizualizuje główne przesłanie tekstu: zamknięte pudełko z niewidzialną owcą, staje się symbolem tego, co niewidzialne dla oczu. A przewrotnie dzieje się to przez medium obrazu, którego zadaniem jest wizualna reprezentacja. $\mathrm{W}$ ten sposób rysunek stał się znakiem autoreferencyjnym, wskazującym na granice własnego medium. Uchylając pokrywę pudełka z niewidzialną owcą Małego Księcia, Mahler dopowiada zawarte w tekście treści: otwartą pokrywę pudełka można odczytać nie tylko jako aluzję do procesu nauki widzenia oczyma wyobraźni inicjowanego przez tekst, ale także - jako element auto-referencyjny - do otwierania tekstu na nowe odczytania w przekładzie.

Paradygmat ilustrowania Mahlera implikuje przesunięcie funkcji ilustracji $\mathrm{w}$ stosunku do oryginału (i pozostałych przekładów): podczas gdy w nich obrazki towarzyszą tekstowi, w rysunkach Mahlera tekst podlega interpretacji (por. Nefzer 1993: 28). Poprzez modyfikację bądź dodawanie elementów obrazkowych ilustracje sugerują sens, eksplorują tekst środkami wizualnymi. Dlatego Oittinen (2000: 103, 113) pisze o tym, że ilustracje w szerokim rozumieniu potraktować można jako tłumaczenie tekstu werbalnego. Rysunki Mahlera mają więc znaczny wpływ na odbiór tekstu, współgrają ze strategią tłumacza, który względem oryginału zajmuje pozycję interpretującą i wzbogaca go o nowe znaczenia.

\section{Wnioski}

Przedstawione tu przykłady niemieckich przekładów dzieła Antoine’a de SaintExupéry'ego unaoczniają dylematy tłumacza $\mathrm{w}$ zetknięciu $\mathrm{z}$ intermedialnym charakterem oryginału. Szczególnie w przypadku obierania przez tłumaczy strategii adaptacyjnych oryginalne ilustracje mogą stanowić przeszkodę. Tłumacze i wydawnictwa znajdują różne wyjścia z tego dylematu. Przekład Enzensbergera ignoruje ilustracje i rozwija się w oderwaniu od nich, obniżeniu ulega ranga obrazków w hierarchii elementów znaczeniotwórczych. Lekceważenie intermedialnego charakteru powoduje jednak znaczne zubożenie oryginału. Natomiast Wydawnictwo Insel, dla którego thumaczy Sloterdijk, oferuje nowy paradygmat ilustracji, który współgra z nowym odczytaniem tekstu w przekładzie. Wersja Sloterdijka i Mahlera pokazuje, że zmiana paradygmatu ilustracji jest czymś więcej niż „zmianą dekoracji”. Decyzję tłumacza, aby domagać się nowych ilustracji, odczytywać można jako efekt obranej przez niego strategii translatorskiej, jest bowiem konsekwencją re-kontekstualizacji, która dokonuje się w przekładzie. 


\section{Bibliografia}

\section{Teksty źródłowe}

Caroll L. 2010. Alicja w Krainie Czarów. Po drugiej stronie lustra, przeł. B. Kaniewska, Poznań: Wydawnictwo Vesper.

St. Exupéry A. 1943. Le Petit Prince. Paris: Gallimard.

St. Exupéry A. 1950. Der kleine Prinz, przeł. G. i J. Leitgeb. Düsseldorf: Rauch.

St. Exupéry A. 2009. Der kleine Prinz, przeł. E. Edl. Düsseldorf: Rauch.

St. Exupéry A. 2015. Der kleine Prinz, przeł. P. Stamm. Frankfurt a.M.: Fischer.

St. Exupéry A. 2015a. Der kleine Prinz, przeł. U. Bossier. Stuttgart: Reclam.

St. Exupéry A. 2015b. Der kleine Prinz, przeł H. M. Enzensberger. München: dtv.

St. Exupéry A. 2015c. Der kleine Prinz, przeł. P. Sloterdijk. Berlin: Insel.

\section{Opracowania}

Balcerzan E. 1998. Literatura z literatury (strategie thumacza). Katowice: Śląsk.

Blank J. 2015. Techniken und Strategien der Literaturadaption im Comic. Berlin: Bachmann.

Da Silva I. 1991. Das Bild im Kinderbuch und seine Bedeutung für die Translation. Heidelberg: Universitätsverlag.

Halliday M. 1978. Language as Social Semiotics: the Social Interpretation of Language and Meaning. London: Edward Arnold.

House J. 1997. Translation Quality Assessment: A Model Revisited. Tübingen: Narr.

House J. 2004. Linguistic Aspects of the Translation of Children's Books, w: H. Kittel i inni (red.), Übersetzung, Translation, Traduction. Ein internationales Handbuch zur Übersetzungsforschung, Bd. 1. Berlin, New York: de Gruyter, pp. 683-697.

Hunt P. 2005. Introduction: the expanding world of Children's Literature Studies, w: P. Hunt (red.), Understanding Children's Literature. London: Routledge, pp. 1-14.

Kaniewska B. 2016. O ważności obrazków, czyli ilustracja $w$ książce dziecięcej, w: Seweryna Wysłouch, Beata Przymuszała (red.), Literatura w kręgu sztuki. Tematy konteksty - medialne transformacje. Poznań: Wydawnictwo Poznańskiego Towarzystwa Przyjaciół Nauk, pp. 155-173.

Kazmierska-Jerzyk W. 2010. Dwujęzyczność, polimedialność, intermedialność $i$ transmedialność praktyk artystycznych - alternatywnie wobec tezy o ,jedności ikono-lingwistycznej” komiksu, w: K. Skrzypczyk (red.), Komiks a komiksologia. Ku rozpoznaniu i charakterystyce wzajemnych relacji między gatunkiem i jego teoria. Łódź: Łdk, pp. 50-54.

Klingberg G., Ørvig M., Amor (red.) 1978. Children's Books in Translation. Stockholm: Almqvist\&Wiksell.

Kress G., van Leeuwen T. 2006 (2. wyd.). Reading Images. The Grammar of Visual Design. London, New York: Routledge.

Lathey G. 2010. The Role of Translators in Children's Literature. Invisible Storytellers. New York, London: Routledge.

Lewis S. 2001. Reading Contemporary Picturebooks. London: Routledge.

McCloud S. 2006. Understanding Comics. The invisible Art. New York: Harper Perrenial. 
Beate Sommerfeld: Ilustracja książek dla dzieci jako źródło dylematów tłumacza na przykładzie dwóch niemieckich przekładów Le Petit Prince Antoine'a de Saint-Exupéry'ego

Nefzer I. 1993. Erzählkunst und Illustration: Von der traditionellen Kindergeschichte zum psychologischen Kinderroman. Frankfurt a.M.: Universitätsverlag.

Nodelman P., Meek M. 1990. Words about pictures. Georgia: University Press.

Oittinen R. 2000. Translating for Children. New York, London: Routledge.

O'Sullivan E. 1994. Winnieh-the-Pooh und der erwachsene Leser: Die Mehrfachadressiertheit eines kinderliterarischen Textes im Übersetzungsvergleich, w: H. Ewers, G. Lehnert, E. O'Sullivan (red.), Kinderliteratur im interkulturellen Prozeß. Stuttgart, Weimar: Metzler, pp. 131-153.

O'Sullivan E. 2000. Kinderliterarische Komparatistik. Stuttgart, Weimar: Metzler.

Porębski M. 1980. Czy metaforę można zobaczyć?, w: Teksty, nr 6 (54), pp. 61-78.

Raney K. 1998: Visual Literacy: Issues and Debates. Middlesex: University School of Education.

Reiß K. 1982. Zur Übersetzung von Kinder- und Jugendbüchern, Lebende Sprachen 1, pp. 7-13.

Salisbury M., Styles M. 2012: Children's Picturebooks. The art of visual storytelling. London: Laurence King Publishing.

Schmitz-Emans M. 2015. Nicolas Mahlers Literaturcomics, w: F. Trabert, M. Stuhlfauth-Trabert (red.), Graphisches Erzählen. Neue Perspektiven auf Literaturcomics. Bielefeld: transcript, pp. 19-42.

Schultze, B. Weinhagen, B. 2007. Kinderliteratur und pikto-literarische Intermedialität: Translatorische Variantenbildung an Wilhelm Buschs Max und Moritz, w: H. Kittel i in. (red.), Übersetzung, Translation, Traduction. Ein internationales Handbuch zur Übersetzungsforschung. 2. Berlin, New York: de Gruyter, pp. 1660-1669.

Shavit Z. 1986. Poetics of Children's Literature. Athens Georgia, London.

Sommerfeld B. 2016. Übersetzungskritik. Modelle, Perspektiven, Didaktik. Poznań: Wydawnictwo Naukowe UAM.

Sommerfeld B. 2017. Neues vom Asteroiden B 612 - Die deutschen Neuübersetzungen von „Le Petit Prince“ von Antoine de St. Exupéry aus übersetzungskritischer Perspektive, w: B. Sommerfeld i inni (red.), Übersetzungskritisches Handeln. Modelle und Fallstudien. Frankfurt a.M.: Lang, pp. 69-83.

Sommerfeld B. 2017a. Z romantyzmen albo bez niego - o niektórych polskich i niemieckich przekładów „Le Petit Prince” Antoine’a de Saint-Exupéry'ego, w: E. Pieciul-Karmińska, B. Sommerfeld, A. Fimiak-Chwiłkowska, Między manipulacja a autonomicznościq estetyczna. Przekład literatury dla dzieci. Poznań: Wydawnictwo Naukowe UAM, pp. 47-86.

Stolt B. 1978. How Emil Becomes Michael: On the Translation of Children's Books, w: G. Klingberg, M. Ørvig, S. Amor (red.), Children's Books in Translation. Stockholm: Almqvist\&Wiksell, pp. 130-146.

Tabbert R. 2002. Approaches to the Translation of Children's Literature, Target 2, pp. 303-351.

Wądolny-Tatar K. 2016. Estetyka przeszłości w przekazu dla najmłodszych w świetle uwag o filogenezie kulturowej, Polonistyka. Innowacje, nr 3, pp. 99-108.

Wysłouch S. 1994. Literatura a sztuki wizualne. Warszawa: Wydawnictwo Naukowe PWN. 